\title{
Differential diagnosis of COVID-19 pneumonia from acute heart failure in pandemic: Importance of radiological and laboratory findings
}

\author{
Umut Sabri \\ KASAPOĞLU ${ }^{\mathbf{1}}$ (ID) \\ Abdullah GÖK ${ }^{2}(I D)$ \\ Leman ACUN \\ $\operatorname{DELEN}^{2}(\mathrm{ID})$ \\ Hasan ŞAYAN $^{2}($ ID) \\ Osman KACMAZ ${ }^{2}$ (ID) \\ Özlem ÇAĞASAR ${ }^{3}$ (ID) \\ Rukan KARACA ${ }^{4}($ ID) \\ Ajda GÜNEŞ ${ }^{5}(I D)$ \\ İrem PEMBEGÜL ${ }^{6}(I D)$ \\ Murat YALÇINSOY ${ }^{7}($ ID)
}

Cite this article as: Kasapoğlu US, Gök A, Acun Delen L, Şayan H, Kaçmaz O, Çağasar Ö et al. Differential diagnosis of COVID-19 pneumonia from acute heart failure in pandemic: Importance of radiological and laboratory findings. Tuberk Toraks 2021;69(2):177-186.

\section{Yazışma Adresi (Address for Correspondence)}

\section{Dr. Umut Sabri KASAPOĞLU}

Malatya Eğitim ve Araştırma Hastanesi, Göğüs Hastalıkları ve Yoğun Bakım Kliniği, MALATYA - TÜRKIYE

e-mail: umutkasapoglu@gmail.com

\footnotetext{
CCopyright 2021 by Tuberculosis and Thorax.
}

Available on-line at www.tuberktoraks.org.com
${ }^{1}$ Clinic of Pulmonary and Critical Care Medicine, Malatya Training and Research Hospital, Malatya, Turkey

${ }^{1}$ Malatya Eğitim ve Araştırma Hastanesi, Göğüs Hastalıkları ve Yoğun Bakım Kliniği, Malatya, Türkiye

${ }^{2}$ Clinic of Anesthesiology and Reanimation, Malatya Training and Research Hospital, Malatya, Turkey

${ }^{2}$ Malatya Ĕgitim ve Araştırma Hastanesi, Anesteziyoloji ve Reanimasyon Kliniği, Malatya, Türkiye

${ }^{3}$ Clinic of Infectious Diseases and Clinical Microbiology, Malatya Training and Research Hospital, Malatya, Turkey

${ }^{3}$ Malatya Eğitim ve Araştırma Hastanesi, Enfeksiyon Hastalıkları ve Klinik Mikrobiyoloji Kliniği, Malatya, Türkiye

${ }^{4}$ Clinic of Radiology, Malatya Training and Research Hospital, Malatya, Turkey

${ }^{4}$ Malatya Ĕgitim ve Araştırma Hastanesi, Radyoloji Kliniği, Malatya, Türkiye

${ }^{5}$ Clinic of Hematology, Malatya Training and Research Hospital, Malatya, Turkey

${ }^{5}$ Malatya Ĕgitim ve Araştırma Hastanesi, Hematoloji Kliniği, Malatya, Türkiye

${ }^{6}$ Department of Nephrology, Malatya Turgut Ozal University School of Medicine, Malatya, Turkey

${ }^{6}$ Malatya Turgut Özal Üniversitesi, Nefroloji Bilim Dalı, Malatya, Türkiye

${ }^{7}$ Department of Chest Diseases, Inönü University Faculty of Medicine, Malatya, Turkey

7 İnönü Üniversitesi Tıp Fakültesi, Göğüs Hastalıkları Anabilim Dalı, Malatya, Türkiye

\section{ABSTRACT}

Differential diagnosis of COVID-19 pneumonia from acute heart failure in pandemic: Importance of radiological and laboratory findings

Introduction: COVID-19 pneumonia typically presents with high fever, cough, and shortness of breath and on thorax computed tomography (CT) peripheral ground glass opacities help the diagnosis. Although typical imaging findings for COVID-19 pneumonia are specified in thorax CT, these findings can be 
confused with other diseases. The aim of this study is to investigate the roles of radiological imaging and laboratory findings in the differential diagnosis of COVID-19 pneumonia and acute heart failure (AHF).

Materials and Methods: In the present study, 74 patients who admitted to the emergency department with respiratory distress during the pandemic period and received a diagnosis of COVID-19 pneumonia and AHF were included. Laboratory data and radiological findings of the patients, at the time of admission, were evaluated.

Results: On admission, there was no difference in age, gender between two groups. However, COVID-19 exposure history was found significantly higher in COVID-19 pneumonia patients group $(p<0.001)$. Fever, cough, and fatigue were found significantly higher in the COVID-19 pneumonia patients group $(p<0.001$ ). There was difference of lesions distribution between the two groups, centrally distributed lesions were found significantly higher in acute heart failure patients $(p<0.001)$. Pleural effusion and cardiomegaly were found significantly higher in AHF patients $(p<0.001, p<0.001)$. Counts of the white blood cells and lymphocytes were found significantly lower in COVID-19 pneumonia patients $(p=0.003, p=0.009)$. COVID-19 pneumonia patients had significantly higher levels of CRP, ferritin, LDH and CK compared with AHF patients $(p<0.001, p<0.001, p=0.002, p=0.013)$. However the level of NT-proBNP was found significantly higher in the AHF patients group $(p<0.001)$.

Conclusion: We believe that laboratory data and thorax CT findings can provide beneficial clinical information in differentiating COVID-19 pneumonia from AHF during the pandemic.

Key words: COVID-19; pneumonia; acute heart failure; computed tomography; ground glass opacity

\section{ÖZ}

\section{Pandemide COVID-19 pnömonisinin akut kalp yetmezliğinden ayırıcı tanısı: Radyolojik bulguların ve laboratuvar bulgularının önemi}

Giriş: COVID-19 pnömonisi tipik olarak yüksek ateş, öksürük, nefes darlığı ile klinik prezente olmakta ve toraks BT'de periferal buzlu cam dansitelerinin görülmesi tanıya yardımcı olmaktadır. Her ne kadar toraks BT'de COVID-19 pnömonisi için tipik görüntüleme bulguları belirtilmiş olsa da, COVID-19 pnömonisinin toraks BT görüntüleme bulguları birçok hastalık ile karışabilmektedir. Bu çalışmada radyolojik görüntüleme bulgularının ve laboratuvar bulgularının COVID-19 pnömonisi ve akut kalp yetmezliği (AKY) ayırıCı tanısında yerinin olup olmadı̆̆ının araştırılması amaçlanmıştır.

Materyal ve Metod: Çalışmaya pandemi sürecinde acil servise solunum sıkıntısı ile başvuran, COVID-19 pnömonisi ve AKY tanısı alan toplam 74 hasta dahil edilmiştir. Olguların hastaneye başvuru sırasındaki laboratuar verileri ve radyolojik bulguları değerlendirilmiştir.

Bulgular: Başvuru sırasında, iki grup arasında yaş ve cinsiyet açısından fark yoktu. Bununla birlikte, COVID-19 maruziyet öyküsü, COVID-19 pnömonisi hasta grubunda anlamlı olarak daha yüksek bulundu ( $p<0,001)$. COVID-19 pnömonisi hasta grubunda ateş, öksürük ve yorgunluk anlamlı olarak yüksek bulundu $(p<0,001)$. iki grup arasında lezyon dağılımı açısından farklılıklar mevcuttu, santral yerleşim gösteren lezyonlar AKY hastalarında anlamlı olarak daha yüksek bulundu $(p<0,001)$. AKY hastalarında plevral efüzyon ve kardiyomegali anlamlı olarak yüksek bulundu $(p<0,001, p<0,001)$. COVID-19 pnömonisi olgularında lökosit ve lenfosit sayıları anlamlı olarak düşük bulundu $(p=0,003, p=0,009)$. COVID-19 pnömonisi hastaları, AKY hastalarına kıyasla anlamlı olarak daha yüksek CRP, ferritin, $L D H$ ve $C K$ seviyelerine sahipti $(p<0,001, p<0,001, p=0,002, p=0,013)$. Ancak NT-proBNP düzeyi ABY hasta grubunda anlamlı olarak yüksek bulundu $(p<0,001)$.

Sonuç: Laboratuvar verilerinin ve toraks BT bulgularının pandemi sürecinde COVID-19 pnömonisini AKY'den ayırt etmede faydalı klinik bilgiler sağlayabileceğine inanıyoruz.

Anahtar kelimeler: COVID-19; pnömoni; akut kalp yetmezliği; bilgisayarlı tomografi; buzlu cam opasitesi

\section{INTRODUCTION}

The first cases of severe acute respiratory syndrome coronavirus-2 (SARS-CoV-2), causing pneumonia were reported in China, in December 2019. Shortly after, cases of the novel coronavirus disease 2019 (COVID-19) has become a global public health problem as a result of the rapid increase in the number of cases, worldwide (1-3).

The clinical findings of COVID-19 range from mild symptoms such as asymptomatic disease and mild upper respiratory tract infection to severe viral pneu- monia accompanied by respiratory failure and multiple organ dysfunction, which can result in death. Clinically, COVID-19 pneumonia typically presents with high fever, cough, and shortness of breath, and on thorax computed tomography (CT) the images of peripheral ground glass densities help diagnosis (4-8).

Although typical imaging findings for COVID-19 pneumonia are specified on thorax $\mathrm{CT}$, these findings can be confused with several diseases (9). One of this clinical entity is acute heart failure (AHF), which is a clinical entity characterized by fluid accumulation in the interstitial space and alveolar space as a result of 
the increase in hydrostatic pressure in the pulmonary capillaries, and it is another common cause of GGO observed on thorax CT. Therefore, clinicians may have difficulties in the differential diagnosis of AHF and COVID-19 pneumonia, especially during the COVID-19 pandemic process (10-12).

The fact that pulmonary edema caused by acute heart failure can mimic several diseases in thorax $C T$, may lead to delays in the diagnosis and treatment of these patients. Therefore, in the present study, we aimed to investigate the roles of radiological findings and inflammatory markers in the differential diagnosis of COVID-19 pneumonia and AHF in cases who admit to the emergency department (ED) with complaints of respiratory distress, during the pandemic process.

\section{MATERIALS and METHODS}

\section{Study Design}

This study was conducted as a retrospective cohort study on patients who admitted to the Emergency Department of Malatya Training and Research Hospital and hospitalized in the intensive care unit (ICU) with the diagnosis of acute respiratory failure, between May 15, 2020 and July 30, 2020. A total of 74 adult patients (aged $\geq 18$ years) consisting of 39 patients who were diagnosed with COVID-19 pneumonia and 35 patients who were diagnosed with AHF after excluding COVID-19 pneumonia, were included in the study. The patients were divided into two groups, namely COVID-19 pneumonia group and AHF group. Laboratory and radiological findings of COVID-19 pneumonia and AHF cases were compared.

\section{Data Collection and Definitions}

The COVID-19 cases were confirmed by real-time reverse transcription polymerase chain reaction (RT-PCR) test from upper respiratory sample (nasopharyngeal and/or oropharyngeal swab) or lower respiratory tract sample (tracheal aspirate), in patients with clinical suspect of positive SARS-CoV-2. In addition, COVID-19 pneumonia cases were defined as symptomatic depending on typical positive thorax CT findings (13). The diagnosis of AHF was based on acute and chronic heart failure guidelines of the European Society of Cardiology (ESC) and at least two consecutive negative COVID-19 RT-PCR tests (14).
The demographic data, vital signs, complaints, comorbidities, biochemistry results, complete blood count results, coagulation parameters (D-dimer, fibrinogen), inflammatory markers (C-reactive protein $(\mathrm{CRP})$, procalcitonin (PCT), ferritin, albumin, and cardiac enzyme values of the patients, at the time of admission, were recorded. The data were obtained by scanning the hospital medical record system and picture archive and communication system (PACS), retrospectively.

\section{Computed Tomography Image Acquisition and Radiological Interpretation}

All thorax CT scans were collected at the end of inspiration with patients in the supine position without injection of contrast agent. 128-slice multi detector CT device (Philips Ingenuity, Philips Systems, Cleveland, $\mathrm{OH}$, USA) was used for all thorax $\mathrm{CT}$ examination. The thorax CT scanning range included the whole chest from the level of the upper thoracic inlet to the diaphragm. Thorax $\mathrm{CT}$ images were evaluated with mediastinal (width, $350 \mathrm{HU}$; level, $40 \mathrm{HU}$ ) and parenchymal (width, $1500 \mathrm{HU}$; level, - $700 \mathrm{HU}$ ) windows settings. The scanning parameters were as follows: $140 \mathrm{kV}, 20-665 \mathrm{~mA}, 0.625 \mathrm{~mm}$ slice collimation, reconstruction matrix of $512 \times 512$, slice thickness of (helical mode) $0.67-5 \mathrm{~mm}$, slice thickness of (axial mode) 0.625-12.5 mm.

Patients that underwent thorax CT evaluation at the time of hospital admission were in-cluded in the study. Thorax CT images of the patients were evaluated blindly by a radiologist experienced in chest radiology. The presence or absence of the thorax CT findings including ground-glass opacities (GGO), consolidation, crazy paving pattern, air bronchogram, distribution of lesions, pleural effusion, involvement of lobes, and cardiomegaly were recorded.

\section{Statistical Analysis}

In the study, normally distributed data were expressed as mean value \pm standard deviation and data without normal distribution were expressed as median (minmax) values, numbers, and percentages. The distribution of variables was tested by Skewness \& Kurtosis. In the comparisons of two independent groups, the independent variables were compared by using t test for the analysis of the parametric data. The Mann Whitney $U$ test was used for the analysis of the nonparametric data and the Chi-Squared test was used for the analysis of the categorical data. SPSS version 
23.0 was used for all analyzes. The results were evaluated at $95 \%$ confidence interval and a value of $p<0.05$ was accepted statistically significant.

The study protocol was approved by Turkish Ministry of Health and Clinical Ethics Committee of Inonu University (protocol code: 2020/125). Since the study was conducted retrospectively, written informed consent form was not obtained from the patients.

\section{RESULTS}

\section{Demographical Characteristics}

A total of 74 patients were enrolled in the study. The patients were divided into two groups as confirmed COVID-19 pneumonia patients $(n=39)$ and AHF $(n=$ 35). Of all the patients, the mean age $68.41 \pm 12.14$ years, and $30(40.5 \%)$ female and $44(59.5 \%)$ were males. COVID-19 exposure history was found significantly higher in the COVID-19 pneumonia patients' group $(p<0.001)$. Chronic kidney disease and chronic heart failure respectively were found significantly higher in the AHF patients' group $(p=0.002, p<$ 0.001 ). There was no difference in age, gender between two groups. The baseline demographic characteristics of the two groups are summarized in Table 1.

The most common complaints of the patients at the hospital admission were shortness of breath in 71 $(95.9 \%)$ patients, cough in $37(50 \%)$ patients, and fever in $29(39.2 \%)$ patients. We found that the fever, cough, and fatigue were significantly higher in the COVID-19 pneumonia patients' group $(p<0.001)$ (Table 2).

\section{Comparison of Radiological and Laboratory Findings}

We found that there were too many radiological differences between the two groups. There was significant difference of lesions distribution between the two groups, centrally distributed lesions were found significantly higher in AHF patients ( $85.8 \%$ vs. $23 \%$, $\mathrm{p}<0.001$ ) (Figure 1). There were also differences between the two groups for ground-glass opacity, consolidation, crazy paving patterns respectively $(p=$ 0.016, $p=0.004, p=0.001$ ). Pleural effusion and cardiomegaly were found significantly higher in AHF patients $(p<0.001, p<0.001)$ (Figure 2). The comparison of thorax CT imaging findings were summarized in Table 3.

On the emergency department admission, counts of the white blood cells and lymphocytes were found significantly lower in COVID-19 pneumonia patients $\left(10.07 \pm 4.8910^{9} / \mathrm{L}\right.$ vs $14.22 \pm 6.6010^{9} / \mathrm{L}, \mathrm{p}=0.003$, $0.7410^{9} / \mathrm{L}(0.26-2.35)$ vs $1.6810^{9} / \mathrm{L}(0.24-10.23), \mathrm{p}=$

\begin{tabular}{|c|c|c|c|c|}
\hline & $\begin{array}{c}\text { All patients } \\
(n=74)\end{array}$ & $\begin{array}{c}\text { Confirmed COVID-19 } \\
\text { pneumonia }(n=39)\end{array}$ & $\begin{array}{l}\text { Acute heart failure } \\
\qquad(n=35)\end{array}$ & $\mathbf{p}$ \\
\hline Age, years $($ Mean $\pm S D)$ & $68.41 \pm 12.14$ & $69.54 \pm 11.53$ & $67.14 \pm 12.83$ & $0.400^{* *}$ \\
\hline \multicolumn{5}{|l|}{ Sex } \\
\hline Female & $30(40.5 \%)$ & $12(30.7 \%)$ & $18(51.4 \%)$ & \multirow[t]{2}{*}{$0.071^{*}$} \\
\hline Male & $44(59.5 \%$ & $27(69.2 \%)$ & $17(48.5 \%)$ & \\
\hline \multicolumn{5}{|c|}{ COVID-19 exposure history } \\
\hline Present & $31(41.9 \%)$ & $30(76.9 \%)$ & $0(0 \%)$ & \multirow[t]{2}{*}{$<0.001 *$} \\
\hline Absent & $43(58.1 \%)$ & $9(23.1 \%)$ & $34(100 \%)$ & \\
\hline \multicolumn{5}{|l|}{ Comorbidities } \\
\hline Malignancy & $4(5.4 \%)$ & $1(2.5 \%)$ & $3(8.5 \%)$ & $0.254^{*}$ \\
\hline CKD & $8(10.8 \%)$ & $0(0 \%)$ & $8(22.8 \%)$ & $0.002 *$ \\
\hline Alzheimer disease & $9(12.2 \%)$ & $1(2.5 \%)$ & $2(5.7 \%)$ & $0.108^{*}$ \\
\hline Diabetes mellitus & $27(36.5 \%)$ & $13(33.3 \%)$ & $14(40 \%)$ & $0.552 *$ \\
\hline Hypertension & $66(89.2 \%)$ & $32(82 \%)$ & $34(97.1 \%)$ & $0.037^{*}$ \\
\hline COPD & $25(33.8 \%)$ & $10(25.6 \%)$ & $15(42.8 \%)$ & $0.118^{*}$ \\
\hline $\mathrm{CHF}$ & $34(45.9 \%)$ & $10(25.6 \%)$ & $24(68.5 \%)$ & $<0.001 *$ \\
\hline IHD & $31(41.9 \%)$ & $16(41 \%)$ & $15(42.8 \%)$ & $0.873^{*}$ \\
\hline Cardiac arrhythmia & $9(12.2 \%)$ & $6(15.3 \%)$ & $3(8.5 \%)$ & $0.371^{*}$ \\
\hline \multicolumn{5}{|c|}{$\begin{array}{l}\text { CKD: Chronic kidney disease, COPD: Chronic obstructive pulmonary disease, CHF: Chronic heart failure, IHD: Ischemic heart disease. } \\
* \text { Chi-square test. } \\
* * \text { Independent samples t test. }\end{array}$} \\
\hline
\end{tabular}


Table 2. Clinical signs and symptoms of the patients

\begin{tabular}{|c|c|c|c|c|}
\hline & $\begin{array}{l}\text { All patients } \\
(n=74)\end{array}$ & $\begin{array}{c}\text { Confirmed COVID-19 } \\
\text { pneumonia }(n=39)\end{array}$ & $\begin{array}{l}\text { Acute heart failure } \\
\qquad(n=35)\end{array}$ & $\mathbf{p}$ \\
\hline \multicolumn{5}{|l|}{ Onset symptoms } \\
\hline Fever & $29(39.2 \%)$ & $28(71.7 \%)$ & $1(2.8 \%)$ & $<0.001 *$ \\
\hline Cough & $37(50 \%)$ & $32(94.8 \%)$ & $5(14.2 \%)$ & $<0.001^{*}$ \\
\hline Dyspnea & $71(95.9 \%)$ & $36(92.3 \%)$ & $35(100 \%)$ & 0.094* \\
\hline Fatigue & $15(20.3 \%)$ & $14(35.8 \%)$ & $1(2.8 \%)$ & $<0.001 *$ \\
\hline Pretibial edema & $19(25.7 \%)$ & $0(0 \%)$ & $19(54.2 \%)$ & $<0.001 *$ \\
\hline Chest pain & $5(6.8 \%)$ & $2(5.1 \%)$ & $3(8.5 \%)$ & $0.556^{*}$ \\
\hline Presence of the fever in hospital admission & $28(37.8 \%)$ & $28(71.8 \%)$ & $0(0 \%)$ & $<0.001 *$ \\
\hline
\end{tabular}
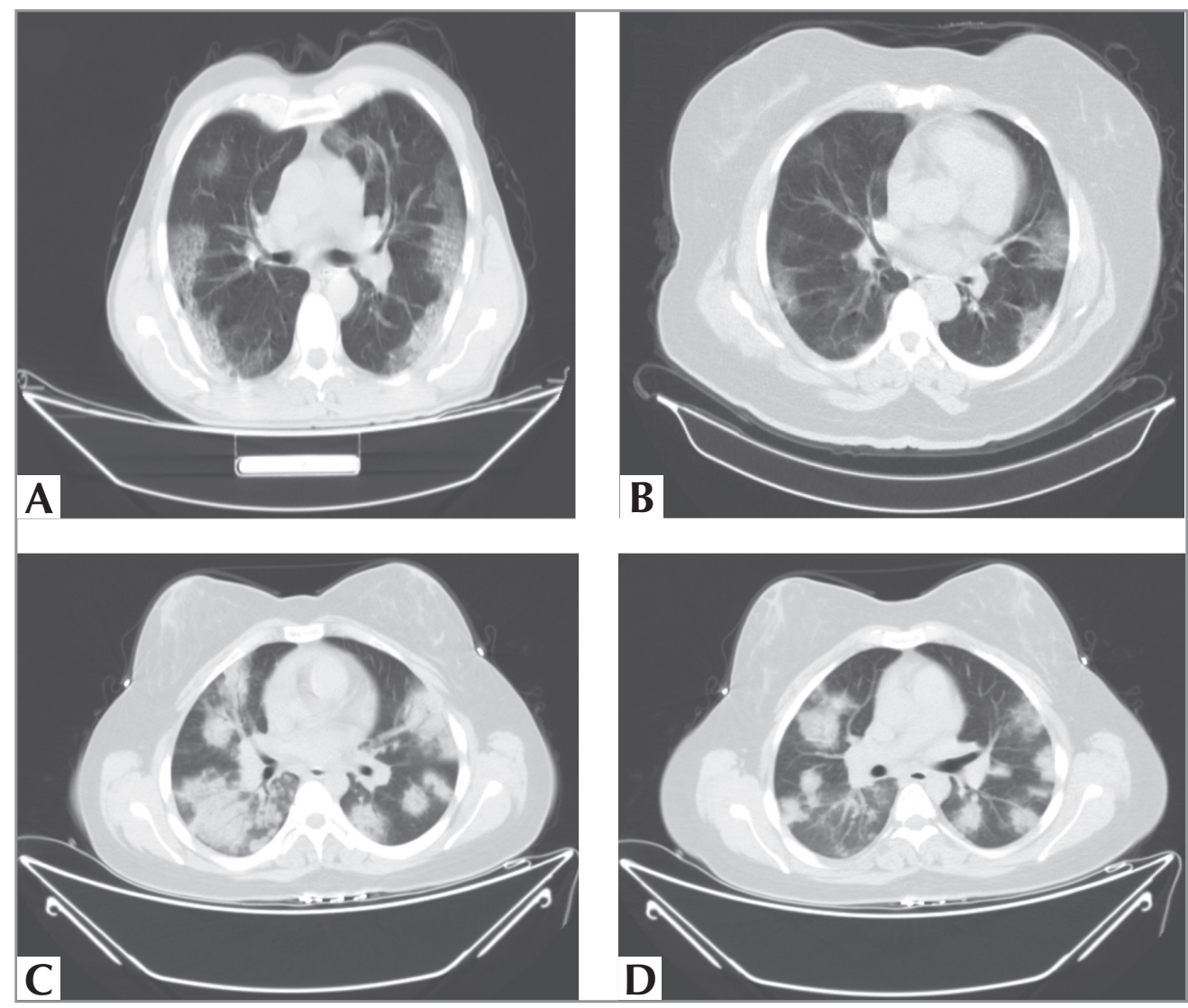

Figure 1. Axial plane of thorax CT images in patients with COVID-19 pneumonia showing A. Bilateral subpleural patchy ground-glass opacities (GGOs), consolidations, and crazy paving patterns in right lobe. B. Bilateral subpleural patchy GGOs and consolidations. C. Bilateral subpleural consolidation and air bronchogram sign, D. Bilateral subpleural patchy GGOs and consolidations.

0.009). Compared with AHF, COVID-19 pneumonia patients had higher levels of lactate dehydrogenase $(\mathrm{LDH})$, creatine kinase $(\mathrm{CK})$ and ferritin $(524 \mathrm{IU} / \mathrm{L}$ (242-1904) vs $363 \mathrm{IU} / \mathrm{L}(136-986) \mathrm{p}=0.002,152 \mathrm{U} / \mathrm{L}$ (20-1416) vs $89 \mathrm{U} / \mathrm{L}(20-519) \mathrm{p}=0.013,873.47 \pm$ $643.96 \mathrm{ng} / \mathrm{mL}$ vs $261.53 \pm 401.28 \mathrm{ng} / \mathrm{mL} \mathrm{p}<0.001)$.
Although patients in both groups had an increased level of CRP, COVID-19 pneumonia patients had significantly higher levels of CRP compared with AHF patients $(15.33 \pm 7.19 \mathrm{mg} / \mathrm{dL}$ vs $5.43 \pm 6.62 \mathrm{mg} /$ $\mathrm{dL}, \mathrm{p}<0.001)$. Also, the level of NT-proBNP was found significantly higher in the AHF patients' group 

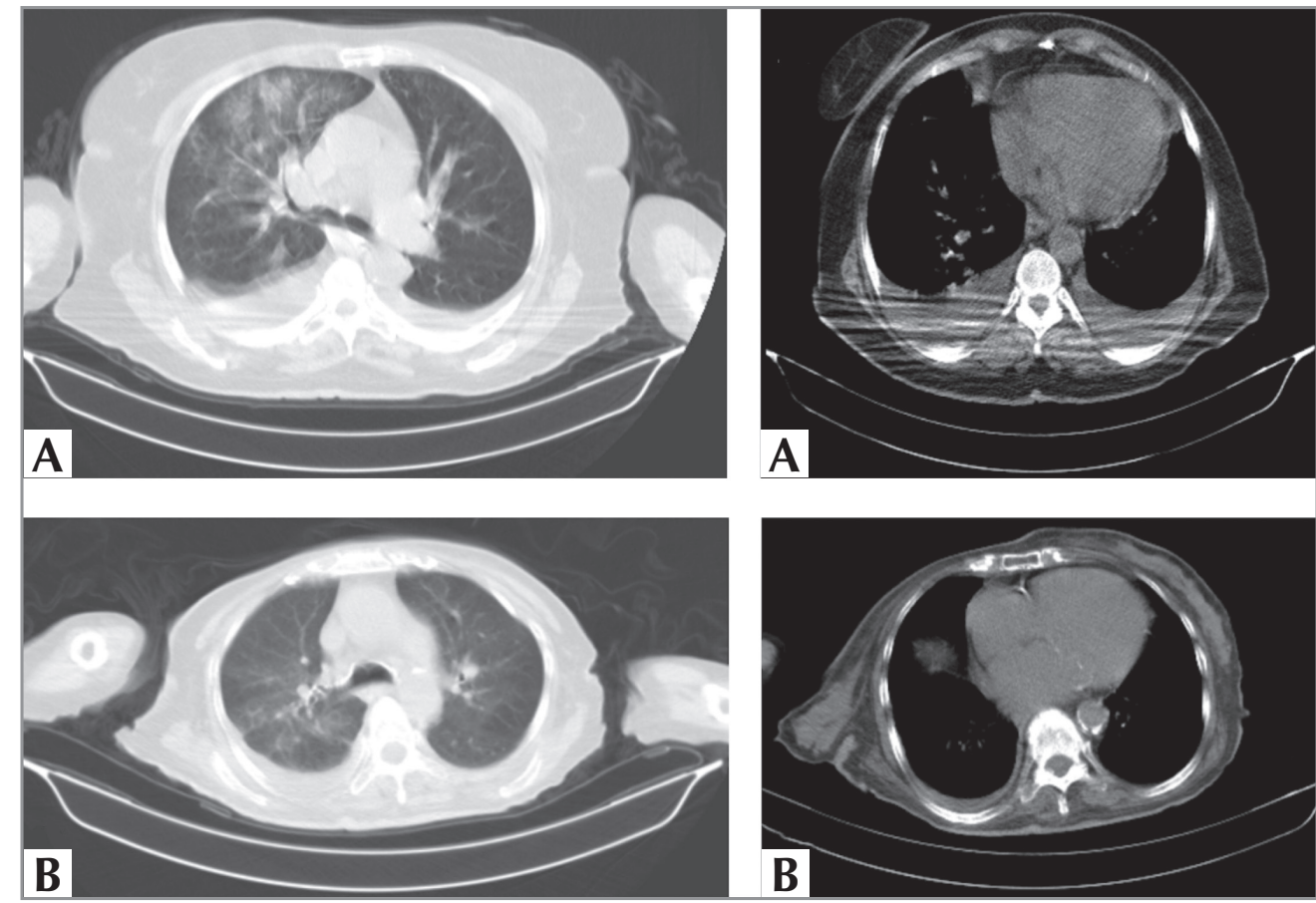

Figure 2. Axial plane of thorax CT images in patients with AHF showing A. Predominantly centrally located GGOs and consolidations, and bilateral pleural effusions. B. Predominantly centrally located bilateral GGOs, pleural effusions in the right lung with cardiomegaly.

Table 3. Thorax CT findings of the patients

\begin{tabular}{|c|c|c|c|c|}
\hline & $\begin{array}{l}\text { All patients } \\
(n=74)\end{array}$ & $\begin{array}{c}\text { Confirmed COVID-19 } \\
\text { pneumonia }(n=39)\end{array}$ & $\begin{array}{l}\text { Acute heart failure } \\
\qquad(n=35)\end{array}$ & $\mathbf{p}$ \\
\hline Ground glass opacity & $66(89.2 \%)$ & $38(97.4 \%)$ & $28(80 \%)$ & $0.016^{*}$ \\
\hline Consolidation & $59(79.7 \%)$ & $36(92.3 \%)$ & $23(65.7 \%)$ & 0.004* \\
\hline Crazy paving pattern & $11(14.9 \%)$ & $11(28.2 \%)$ & $0(0 \%)$ & $0.001 *$ \\
\hline Air bronchogram & $11(14.9 \%)$ & $10(25.6 \%)$ & $1(2.8 \%)$ & 0.006* \\
\hline \multicolumn{5}{|l|}{ Distribution of lung lesions } \\
\hline Peripheral distribution & $40(54 \%)$ & $35(89.7 \%)$ & $5(14.2 \%)$ & $<0.001^{*}$ \\
\hline Central distribution & $34(46 \%)$ & $4(10.3 \%)$ & $30(85.8 \%)$ & $<0.001^{*}$ \\
\hline \multicolumn{5}{|l|}{ Pulmonary lobe involvement } \\
\hline Upper lobe & $48(64.9 \%)$ & $32(82 \%)$ & $16(45.7 \%)$ & $0.001 *$ \\
\hline Middle/lingular lobe & $58(78.4 \%)$ & $34(89.7 \%)$ & $24(68.5 \%)$ & $0.052^{*}$ \\
\hline Lower lobe & $65(87.8 \%)$ & $33(84.6 \%)$ & $32(91.4 \%)$ & $0.371^{*}$ \\
\hline Pleural effusion & $27(36.5 \%)$ & $1(2.5 \%)$ & $26(74.2 \%)$ & $<0.001 *$ \\
\hline Cardiomegaly & $38(51.4 \%)$ & $6(15.3 \%)$ & $32(91.4 \%)$ & $<0.001 *$ \\
\hline
\end{tabular}

$(3975 \pm 8288 \mathrm{pg} / \mathrm{mL}$ vs $17251 \pm 15233 \mathrm{pg} / \mathrm{mL}, \mathrm{p}<$ 0.001). A comparison of the laboratory data was summarized in Table 4.

\section{DISCUSSION}

Acute heart failure is one of the most common cardiac emergencies. In AHF patients, the precipitating factors that require urgent intervention should be 


\begin{tabular}{|c|c|c|c|c|}
\hline & $\begin{array}{l}\text { All patients } \\
\quad(n=74)\end{array}$ & $\begin{array}{l}\text { Confirmed COVID-19 } \\
\text { pneumonia }(n=39)\end{array}$ & $\begin{array}{l}\text { Acute heart failure } \\
\qquad(n=35)\end{array}$ & $\mathbf{p}$ \\
\hline \multicolumn{5}{|l|}{ Biochemical parameters } \\
\hline Urea, mg/dL (min-max) & $57(11-388)$ & $43(11-183)$ & $69(29-388)$ & $0.006 *$ \\
\hline Creatinin, mg/dL (min-max) & $1.08(0.36-7.32)$ & $0.93(0.36-2.09)$ & $1.46(0.61-7.32)$ & 0.003* \\
\hline AST, U/L (min-max) & $43.50(10-940)$ & $51(17-940)$ & $27.50(10-313)$ & $0.010^{*}$ \\
\hline $\mathrm{ALT}, \mathrm{U} / \mathrm{L}(\min -\max )$ & $28(4-850)$ & $29(16-850)$ & $23(4-296)$ & $0.120^{*}$ \\
\hline LDH, IU/L (min-max) & $461(136-1904)$ & $524(242-1904)$ & $363(136-986)$ & $0.002 *$ \\
\hline CK, U/L (min-max) & $118(20-1416)$ & $152(20-1416)$ & $89(20-519)$ & $0.013^{*}$ \\
\hline Albumin, g/dL (min-max) & $3.20(2.23-4.34)$ & $3.10(2.30-3.80)$ & $3.40(2.23-4.344)$ & 0.039* \\
\hline \multicolumn{5}{|l|}{ Cardiac enzymes } \\
\hline NT-proBNP, pg/mL (Mean \pm SD) & $10340 \pm 13765$ & $3975 \pm 8288$ & $17251 \pm 15233$ & $<0.001^{* *}$ \\
\hline Trop-I, ng/mL (min-max) & $0.10(0.10-21.29)$ & $0.10(0.10-3.53)$ & $0.12(0.10-21.29)$ & $0.112^{*}$ \\
\hline \multicolumn{5}{|l|}{ Coagulation parameters } \\
\hline Fibrinojen, ng/dL (min-max) & $391(143-1066)$ & $473(200-1066)$ & $350(143-676)$ & $0.001 *$ \\
\hline D-dimer, $\mu \mathrm{g} / \mathrm{mL}$ (min-max) & $2.16(0.19-25.20)$ & $2.15(0.19-24.40)$ & $2.33(0.19-25.20)$ & $0.808^{*}$ \\
\hline INR, (min-max) & $1.24(0.90-2.57)$ & $1.22(0.90-2.57$ & $1.26(1.04-2.52)$ & $0.038^{*}$ \\
\hline \multicolumn{5}{|l|}{ Total blood count } \\
\hline Wbc, $10^{9} / \mathrm{L}($ Mean $\pm \mathrm{SD})$ & $12.03 \pm 6.09$ & $10.07 \pm 4.89$ & $14.22 \pm 6.60$ & $0.003^{* *}$ \\
\hline Neu, $10^{9} / \mathrm{L}($ Mean $\pm \mathrm{SD})$ & $9.25(3.10-3.76)$ & $8.73(1.93-20.92)$ & $10.37(2.46-26.19)$ & $0.110^{*}$ \\
\hline Lymph, $10^{9} / \mathrm{L}($ Mean $\pm \mathrm{SD})$ & $0.84(0.23-10.23)$ & $0.74(0.26-2.35)$ & $1.68(0.24-10.23)$ & $0.009 *$ \\
\hline $\mathrm{Hgb}, \mathrm{g} / \mathrm{dL}($ Mean $\pm \mathrm{SD})$ & $12.34 \pm 1.91$ & $12.88 \pm 1.63$ & $11.74 \pm 2.04$ & $0.010^{* *}$ \\
\hline Htc, \% (Mean \pm SD) & $38.40 \pm 5.83$ & $38.71 \pm 4.91$ & $38.06 \pm 6.77$ & $0.633^{* *}$ \\
\hline Plt, $10^{9} / \mathrm{L}($ Mean $\pm \mathrm{SD})$ & $237 \pm 107$ & $223 \pm 105$ & $252 \pm 109$ & $0.237^{* *}$ \\
\hline \multicolumn{5}{|l|}{ Arterial blood gas analysis } \\
\hline $\mathrm{pH},($ Mean $\pm \mathrm{SD})$ & $7.38 \pm 0.11$ & $7.42 \pm 0.91$ & $7.33 \pm 0.11$ & $<0.001^{* *}$ \\
\hline $\mathrm{Po}_{2}, \mathrm{mmHg}(\min -\mathrm{max})$ & $67.75(32-142)$ & $54(32-142)$ & $75.30(46-130)$ & $<0.001^{*}$ \\
\hline $\mathrm{PCO}_{2}, \mathrm{mmHg}($ Mean $\pm \mathrm{SD})$ & $39.85 \pm 14.65$ & $35.61 \pm 9.00$ & $44.58 \pm 18.06$ & $0.008^{* *}$ \\
\hline $\mathrm{HCO}_{3}, \mathrm{mEq} / \mathrm{L}(\min -\mathrm{max})$ & $23.35(11.40-41.00)$ & $23.30(16.20-31.50)$ & $23.50(11.40-41.00)$ & $0.577^{*}$ \\
\hline $\mathrm{Spo}_{2}, \%($ Mean $\pm \mathrm{SD})$ & $88.94 \pm 8.71$ & $85.60 \pm 9.99$ & $92.67 \pm 4.92$ & $<0.001^{* *}$ \\
\hline Lactate, mmol/L (min-max) & $2.00(0.50-14.00)$ & $1.80(0.50-4.80)$ & $2.30(0.50-14.00)$ & $0.131^{*}$ \\
\hline \multicolumn{5}{|l|}{ Inflammatory parameters } \\
\hline $\mathrm{CRP}, \mathrm{mg} / \mathrm{dL}($ Mean $\pm \mathrm{SD})$ & $10.64 \pm 8.49$ & $15.33 \pm 7.19$ & $5.43 \pm 6.62$ & $<0.001^{* *}$ \\
\hline PCT, ng/mL (min-max) & $0.41(0.04-97.50)$ & $0.37(0.05-59.78)$ & $0.43(0.04-97.50)$ & $0.630^{*}$ \\
\hline Ferritin, ng/mL (Mean $\pm \mathrm{SD})$ & $580.07 \pm 619.60$ & $873.47 \pm 643.96$ & $261.53 \pm 401.28$ & $<0.001^{* *}$ \\
\hline \multicolumn{5}{|c|}{$\begin{array}{l}\text { Me: Mean, SD: Standard derivation, AST: Aspartate aminotransferase, ALT: Alanine aminotransferase, LDH: Lactate dehydrogenase, CK: Creatin } \\
\text { kinase PCT: Procalcitonin, NT-proBNP: N-terminal prohormone of brain natriuretic peptide, CRP: C-reactive protein, Lymph: lymphocyte } \\
\text { Wbc: White blood cell, Neu: Neutrophil, Hgb: Hemoglobin, Htc: Hematocrit, Plt: Platelets, INR: International normalized ratio, Trop-l: Troponin- } \\
\text { * Mann-Whitney U test. } \\
* \text { Independent samples t test. }\end{array}$} \\
\hline
\end{tabular}

identified and corrected immediately. Since AHF is a life-threatening clinical condition, delays in diagnosis and treatment are associated with increased mortality and morbidity (15-17). However, in thorax CT findings, pulmonary edema caused by AHF can be confused with several exudative diseases and may cause delays in diagnosis and treatment, especially during the pandemic process (18).

Acute heart failure is a condition that heart failure symptoms and signs get worse quickly. AHF can be in the form of new-onset heart failure or more frequently as acute decompensation of chronic heart failure $(14,17,19)$. In our study, $68.5 \%$ of AHF cases were previously treated for chronic heart failure. Although typical symptoms and signs of AHF are mostly caused by excess volume (pulmonary congestion, peripheral edema), in some cases it may be associated with hypoperfusion resulted by low cardiac output. However, due to the low sensitivity and specificity of symptoms and signs, further evaluation is required in 
most cases $(14,17)$. In our study, in line with the literature, the most common symptoms in AHF cases were shortness of breath $(100 \%)$, pretibial edema $(54.2 \%)$, and cough $(14.2 \%)$, respectively.

The clinical manifestations of COVID-19 cases range from mild manifestations such as asymptomatic disease and mild upper respiratory tract infection to severe viral pneumonia that can lead to acute respiratory failure and death. Fever, cough, headache and weakness are the most common symptoms at the beginning of the disease. However, in $20 \%$ of the cases, pneumonia, which is the most serious and common presentation of the disease, may develop. This period is called the pulmonary phase of the disease and it is reported that shortness of breath is a common symptom on admission to the emergency department (5,8,20-25). Consistent with the literature, in our study, the most common symptoms in COVID-19 pneumonia patients were cough $(94.8 \%)$, shortness of breath $(92.3 \%)$, and fever $(71.7 \%)$, respectively.

Pretibial edema due to the excess volume was found more frequently in AHF cases. Moreover, while fever was detected in $71.8 \%$ of COVID-19 pneumonia cases at the time of admission to the ED, it was not found in any of the AHF cases ( $p<0.001)$. In addition, while a history of contact with a COVID-19 patient was $76.9 \%$ in COVID-19 pneumonia group, none of the AHF cases had a history of contact with a COVID19 patient $(p<0.001)$. In the differential diagnosis of AHF from COVID-19 pneumonia during the pandemic pro-cess, COVID-19 contact history, symptoms and findings can provide important information to clinicians, in the first evaluation.

Detecting suspicious cases as soon as possible during the COVID-19 pandemic process is the most important point in controlling the spread of the disease (18). The gold standard method in the diagnosis of COVID19 is detection of viral nucleic acids by RT-PCR testing method. Although RT-PCR test has high specificity in diagnosis, its sensitivity is low due to its false negative results. For this reason, it has been suggested that the test is insufficient. In addition, achieving results in an average of 15 hours may cause delays in diagnosis and treatment $(4,26-29)$.

Thorax CT has become an important tool in the diagnosis and follow-up of COVID-19 cases, thanks to the specific pathological findings in thorax CT images. In COVID-19 cases, pathological findings can be detected in thorax CT images, despite negative RT-PCR test results, and even when the patients are in the asymptomatic period. Although thorax CT is not the gold standard diagnostic test in COVID-19 cases, it can be helpful in diagnosis and differential diagnosis. In COVID-19 pneumonia, thorax CT typically shows bilateral peripheral and/or subpleural ground glass opacities, multifocal patchy consolidations, and crazy paving pattern $(4,26,27,30-35)$. In our study, consistent with the literature, the most common thorax CT findings in COVID-19 pneumonia cases were groundglass opacities $(97.4 \%)$, consolidations $(92.3 \%)$ and crazy paving pattern (28.2\%) with peripheral location.

Although typical findings in thorax CT imaging for COVID-19 pneumonia are described, these findings can be confused with several diseases. AHF is another clinical condition, which is a common cause of ground glass densities observed in thorax CT images. In AHF, contrary to COVID-19 pneumonia, the ground glass densities observed predomi-nantly in the central parts, whereas peripheral parts of the lung are protected. On the other hand, in AHF, other differential findings observed in thorax $\mathrm{CT}$ images are pleural effusion, mediastinal lymphadenopathy, septal thickening, and enlarged pulmonary veins $(9,11,18,33,36)$. In our study, similar to the literature, ground glass opacities $(80 \%)$ and consolidations $(65.7 \%)$ were predominantly located in the central and lower lobes, in AHF patients. In addition, cardiomegaly in $91.4 \%$ and pleural effusion was found in $74.2 \%$ of the cases.

In our study, in COVID-19 pneumonia cases thorax CT lesions were mostly located in the peripheral parts, whereas lesions in AHF cases were mostly centrally located. In addition, pleural effusion and cardiomegaly findings were detected more frequently in AHF cases compared to COVID-19 cases. It should be noted that, the distribution of lesions on thorax CT images and the presence of pleural effusion and cardiomegaly can provide important information to clinicians in the first evaluation in the emergency department.

In COVID-19 patients, in the early period of the disease, lymphopenia is prominent in complete blood count and as the disease progresses, the lymphocyte count continues to decrease, whereas inflammatory markers increase $(25,35,37,38)$. In our study, consistent with the literature, the mean lymphocyte count was lower in COVID-19 pneumonia group compared to the AHF group ( $p=0.009)$. In addition, in the studies it has been shown that lymphopenia 
and high serum ferritin, D-dimer, CRP, troponin, and LDH levels in COVID-19 cases were associated with poor prognosis and increased mortality (37-42). In our study, LDH, CK, CRP, and ferritin levels were increased in both groups; however mean levels of LDH, CK, CRP and ferritin were significantly higher in COVID-19 pneumonia group $(p=0.002, p=0.013$, $\mathrm{p}<0.001, \mathrm{p}<0.001$, respectively). Similarly, although the levels NT-proBNP were increased in both groups, it was significantly higher in the AHF group $(\mathrm{p}<$ 0.001).

\section{LIMITATIONS}

Present study has some limitations. Firstly, this is a single center retrospective cohort study with relatively small sample size. Secondly, all thorax CT findings are reviewed by a single radiologist experienced in chest radiology.

\section{CONCLUSION}

In conclusion, we think that contact history, laboratory data and thorax CT findings can be useful in distinguishing acute heart failure from COVID-19 pneumonia in patients who admitted to the emergency department with respiratory distress during the pandemic process and can provide very important information to clinicians.

Ethical Committee Approval: The study protocol was approved by Turkish Ministry of Health and Clinical Ethics Committee of Inonu University (protocol code: 2020/125).

\section{CONFLICT of INTEREST}

The authors of this meta-analysis declare that they have no conflict of interest.

\section{AUTHORSHIP CONTRIBUTIONS}

Concept/Design: USK, AG, LAD, IP, ÖC, OK

Analysis/Interpretation: USK, AG, MY, RK, HŞ, OK

Data Acqusition: USK, HŞ, OK, ÖC, RK,

Writing: USK, AG, LAD, MY, RK, HŞ, ÖC

Clinical Revision: MY, USK, IP, AG, RK

Final Approval: USK, MY, LAD, AG, iP

\section{REFERENCES}

1. Grasselli G, Zangrillo A, Zanella A, Antonelli M, Cabrini L, Castelli $A$, et al. Baseline Characteristics and outcomes of 1591 patients infected with SARS-CoV-2 admitted to ICUs of the Lombardy Region, Italy. JAMA 2020; 323(16): 1574-81.
2. Huang $C$, Wang Y, Li X, Ren L, Zhao J, Hu Y, et al. Clinical features of patients in-fected with 2019 novel coronavirus in Wuhan, China. Lancet 2020; 395(10223): 497-506.

3. Richardson S, Hirsch JS, Narasimhan M, Crawford IM, McGinn T, Davidson KW, et al. Presenting characteristics, comorbidities, and outcomes among 5700 patients hospitalized with COVID-19 in the New York City Area. JAMA 2020; 323(20): 2052-59.

4. Dong $X$, Cao $Y Y, L u X X$, Zhang IJ, Du H, Yan YQ, et al. Eleven faces of coronavirus disease 2019. Allergy 2020; 75(7): 1699-709.

5. Odabasi Z, Cinel I. Consideration of severe coronavirus disease 2019 as viral sepsis and potential use of immune checkpoint inhibitors. Crit Care Explor 2020; 2(6): e0141.

6. Stone $J H$, Frigault MJ, Serling-Boyd NJ, Fernandes AD, Harvey L, Foulkes AS, et al. Efficacy of tocilizumab in patients hospitalized with Covid-19. N Engl J Med 2020. 2020/10/22.

7. Wu Z, McGoogan JM. Characteristics of and important lessons from the corona-virus disease 2019 (COVID-19) outbreak in China: Summary of a report of 72314 cases from the chinese center for disease control and prevention. JAMA 2020; 323(13): 1239-42.

8. Zhou F, Yu T, Du R, Fan G, Liu Y, Liu Z, et al. Clinical course and risk factors for mortality of adult inpatients with COVID-19 in Wuhan, China: a retrospective cohort study. Lancet 2020; 395(10229): 1054-62.

9. Luo L, Luo Z, Jia Y, Zhou C, He J, Lyu J, et al. CT differential diagnosis of COVID-19 and non-COVID-19 in symptomatic suspects: a practical scoring method. BMC Pulm Med 2020; 20(1): 129.

10. Bertolino L, Vitrone $M$, Durante-Mangoni E. Does this patient have COVID-19? A practical guide for the internist. Intern Emerg Med 2020; 15(5): 791-800.

11. Hani C, Trieu NH, Saab I, Dangeard S, Bennani S, Chassagnon G, et al. COVID-19 pneumonia: A review of typical CT findings and differential diagnosis. Diagn Interv Imaging 2020; 101(5): 263-68.

12. Parekh M, Donuru A, Balasubramanya R, Kapur S. Review of the chest CT differential diagnosis of ground-glass opacities in the COVID Era. Radiology 2020: 202504.

13. World Health Organization (WHO). Clinical management of COVID-19: interim guidance. 27 May 2020. Available at https://www.who.int/publications/i/item/clinical-management-of-covid-19. Accessed (November 10, 2020). Available from: https://www.who.int/publications/i/item/ clinical-management-of-covid-19.

14. Ponikowski P, Voors AA, Anker SD, Bueno H, Cleland JGF, Coats AJS, et al. 2016 ESC Guidelines for the diagnosis and treatment of acute and chronic heart failure: The Task Force for the diagnosis and treatment of acute and chronic heart failure of the Euro-pean Society of Cardiology (ESC)Developed with the special contribution of the Heart Failure Association (HFA) of the ESC. Eur Heart $)$ 2016; 37(27): 2129-200. 
15. Maisel AS, Peacock WF, McMullin N, Jessie $R$, Fonarow GC, Wynne J, et al. Tim-ing of immunoreactive B-type natriuretic peptide levels and treatment delay in acute decompensated heart failure: an ADHERE (Acute Decompensated Heart Failure National Registry) analysis. J Am Coll Cardiol 2008; 52(7): 534-40.

16. Peacock WF, Emerman C, Costanzo MR, Diercks DB, Lopatin $M$, Fonarow GC. Early vasoactive drugs improve heart failure outcomes. Congest Heart Fail 2009; 15(6): 256-64.

17. Ural D, Cavusog/u Y, Eren M, Karauzum K, Temizhan A, Yilmaz $M B$, et al. Diagno-sis and management of acute heart failure. Anatol J Cardiol 2015; 15(11): 860-89.

18. Zhu Z, Tang J, Chai X, Fang Z, Liu Q, Hu X, et al. How to differentiate COVID-19 pneumonia from heart failure with computed tomography at initial medical contact during epidemic period. medRxiv 2020: 2020.03.04.20031047.

19. Mebazaa A, Yilmaz MB, Levy P, Ponikowski P, Peacock WF, Laribi S, et al. Rec-ommendations on pre-hospital \& early hospital management of acute heart failure: a consensus paper from the Heart Failure Association of the European Society of Cardiology, the European Society of Emergency Medicine and the Society of Academic Emergency Medicine. Eur I Heart Fail 2015; 17(6): 544-58.

20. Feng Y, Ling Y, Bai T, Xie Y, Huang J, Li J, et al. COVID-19 with Different severities: a multicenter study of clinical features. Am J Respir Crit Care Med 2020; 201(11): 1380-88.

21. Guan WJ, Ni ZY, Hu Y, Liang WH, Ou CQ, He JX, et al. Clinical characteristics of coronavirus disease 2019 in China. N Engl J Med 2020; 382(18): 1708-20.

22. Lai CC, Shih TP, Ko WC, Tang HI, Hsueh PR. Severe acute respiratory syndrome coronavirus 2 (SARS-CoV-2) and coronavirus disease-2019 (COVID-19): The epidemic and the challenges. Int J Antimicrob Agents 2020; 55(3): 105924.

23. Palmieri L, Palmer K, Lo Noce C, Meli P, Giuliano M, Floridia $M$, et al. Differences in the clinical characteristics of COVID-19 patients who died in hospital during different phases of the pandemic: national data from Italy. Aging Clin Exp Res 2020.

24. Rothan HA, Byrareddy SN. The epidemiology and pathogenesis of coronavirus disease (COVID-19) outbreak. J Autoimmun 2020; 109: 102433.

25. Siddiqi HK, Mehra MR. COVID-19 illness in native and immunosuppressed states: A clinical-therapeutic staging proposal. J Heart Lung Transplant 2020; 39(5): 405-07.

26. Ai T, Yang $Z$, Hou $H$, Zhan $C$, Chen $C, L v W$, et al. Correlation of Chest CT and RT-PCR Testing for Coronavirus Disease 2019 (COVID-19) in China: A Report of 1014 Cas-es. Radiology 2020; 296(2): E32-E40.

27. Li Y, Xia L. Coronavirus Disease 2019 (COVID-19): Role of chest CT in diagnosis and management. AJR Am J Roentgenol 2020; 214(6): 1280-86.

28. Richardson S, Hirsch JS, Narasimhan M, Crawford JM, McGinn T, Davidson KW, et al. Presenting characteristics, comorbidities, and outcomes among 5700 patients hospitalized with COVID-19 in the New York City Area. Jama 2020; 323(20): 2052-9.
29. Wikramaratna P, Paton RS, Ghafari M, Lourenço J. Estimating false-negative de-tection rate of SARS-CoV-2 by RT-PCR. medRxiv 2020: 2020.04.05.20053355.

30. Duan YN, Zhu YQ, Tang LL, Qin J. CT features of novel coronavirus pneumonia (COVID-19) in children. Eur Radiol 2020; 30(8): 4427-33.

31. Fang $Y$, Zhang $H$, Xie J, Lin $M$, Ying $L$, Pang $P$, et al. Sensitivity of chest CT for COVID-19: Comparison to RT-PCR. Radiology 2020; 296(2): E115-E17.

32. Pan F, Ye T, Sun P, Gui S, Liang B, Li L, et al. Time Course of lung changes at chest $C T$ during recovery from Coronavirus Disease 2019 (COVID-19). Radiology 2020; 295(3): 715-21.

33. Parekh M, Donuru A, Balasubramanya R, Kapur S. Review of the chest CT Differ-ential Diagnosis of Ground-Glass Opacities in the COVID Era. Radiology 2020; 297(3): E289-E302.

34. Ye Z, Zhang Y, Wang Y, Huang Z, Song B. Chest CT manifestations of new coro-navirus disease 2019 (COVID-19): a pictorial review. Eur Radiol 2020; 30(8): 4381-9.

35. Zhao D, Yao F, Wang L, Zheng L, Gao Y, Ye J, et al. A comparative study on the clinical features of coronavirus 2019 (COVID-19) pneumonia with other pneumonias. Clin Infect Dis 2020; 71(15): 756-61.

36. Dai WC, Zhang HW, Yu J, Xu HJ, Chen H, Luo SP, et al. CT imaging and differen-tial diagnosis of COVID-19. Can Assoc Radiol I 2020; 71(2): 195-200.

37. Gao Y, Li T, Han M, Li X, Wu D, Xu Y, et al. Diagnostic utility of clinical laboratory data determinations for patients with the severe COVID-19. I Med Virol 2020; 92(7): 79196.

38. Pourbagheri-Sigaroodi A, Bashash D, Fateh F, Abolghasemi H. Laboratory findings in COVID-19 diagnosis and prognosis. Clin Chim Acta 2020; 510: 475-82.

39. Chen $T, W u D$, Chen $H$, Yan $W$, Yang $D$, Chen $G$, et al. Clinical characteristics of 113 deceased patients with coronavirus disease 2019: retrospective study. BMJ 2020; 368: $m 1091$.

40. Javanian M, Bayani M, Shokri M, Sadeghi-Haddad-Zavareh $M$, Babazadeh A, Ye-ganeh B, et al. Clinical and laboratory findings from patients with COVID-19 pneumonia in Babol North of Iran: a retrospective cohort study. Rom J Intern Med 2020; 58(3): 161-7.

41. Ji $D$, Zhang $D, X U$ J, Chen $Z$, Yang $T$, Zhao $P$, et al. Prediction for progression risk in patients with COVID-19 pneumonia: The CALL Score. Clin Infect Dis 2020; 71(6): 1393-99.

42. Lippi G, Plebani M. Laboratory abnormalities in patients with COVID-2019 infection. Clin Chem Lab Med 2020; 58(7): 1131-34 